\title{
Patogeneza zapaleń naczyń związanych z przeciwciałami przeciwko cytoplazmie neutrofilów
}

\section{Pathogenesis of antineutrophil cytoplasmic antibodies-associated vasculitis}

\author{
Łukasz Moos $^{1 凶}$, Przemysław J. Kotyla² \\ ${ }^{1}$ Uniwersytecki Szpital Kliniczny w Opolu, Oddział Chorób Wewnętrznych, Gastroenterologii, Diabetologii i Endokrynologii, al. W. Witosa 26, 45-418 Opole \\ University Hospital, Department of Internal Medicine, Gastroenterology, Diabetology and Endocrinology \\ ${ }^{2}$ Śląski Uniwersytet Medyczny w Katowicach, Katedra i Klinika Chorób Wewnętrznych i Reumatologii, ul. Ziołowa 45/47, 40-635 Katowice \\ Medical University of Silesia in Katowice, Department of Internal Medicine and Rheumatology \\ $\triangle$ lukaszmoos@gmail.com
}

\begin{abstract}
Antineutrophil cytoplasmic antibodies-associated vasculitis (AAV) is a group of autoimmune disorders characterized by necrotizing small-vessel vasculitis, the presence of antineutrophil cytoplasmic antibodies (ANCA), and little or no staining for immunoglobulins and complements in vessel walls by immunofluorescence microscopy examination. Antineutrophil cytoplasmic antibodies are a group of autoantibodies, predominantly immunoglobulins G, against antigens in the cytoplasm of neutrophil granulocytes. The evidence supporting the pathogenicity of ANCA comes from clinical observations, in vitro
\end{abstract}

studies and animal models. The origin of the ANCA autoimmune response is still under examination as there are many mechanisms responsible for the development of AAV which are still not fully understood. We are still accumulating new reports that allow us to better understand the pathogenetic pathways leading to the lesions found in AAV patients.

In this paper we reviewed the most probable mechanisms leading to the formation of ANCA, as well as the possible role of antibodies in the pathogenesis of vasculitides.

Keywords: antineutrophil cytoplasmic antibodies; vasculitides.

\begin{abstract}
ABSTRAKT
Zapalenia naczyń związane z przeciwciałami przeciwko cytoplazmie neutrofilów (antineutrophil cytoplasmic antibodies-associated vasculitis - AAV) to grupa chorób zajmujących małe naczynia i charakteryzujących się ich martwiczym zapaleniem oraz obecnością przeciwciał przeciwko cytoplazmie neutrofilów (antineutrophil cytoplasmic antibodies - ANCA) przy braku lub obecności jedynie skąpej ilości immunoglobulin w ścianie naczyń. Przeciwciała przeciwko cytoplazmie neutrofilów to przeciwciała klasy G skierowane przeciwko składnikom ziarnistości granulocytów obojętnochłonnych. Dowody na udział ANCA w patogenezie AAV pochodzą zarówno z obserwacji klinicznych, badań
\end{abstract}

in vitro, jak i badań na zwierzętach. Przyczyny pojawiania się ANCA są cały czas wnikliwie badane, gdyż istnieje wiele nie w pełni zrozumiałych ścieżek patogenetycznych prowadzących do rozwoju choroby. Wciąż pojawiają się też nowe doniesienia pozwalające lepiej zrozumieć sposób powstawania patologicznych zmian wykrywanych u pacjentów z AAV.

W niniejszej pracy przedstawiono najbardziej prawdopodobne mechanizmy odpowiadające za powstawanie ANCA, jak również możliwą rolę przeciwciał w patogenezie rozwoju zapalenia naczyń.

Słowa kluczowe: przeciwciała przeciwko cytoplazmie neutrofilów; zapalenia naczyń.

\section{WSTĘP}

Zapalenia naczyń związane z przeciwciałami przeciwko cytoplazmie neutrofilów (antineutrophil cytoplasmic antibodies-associated vasculitis - AAV) to grupa chorób zajmujących małe naczynia (włośniczki, żyłki, tętniczki i małe tętnice), które cechują się martwiczym zapaleniem oraz obecnością przeciwciał przeciwko cytoplazmie neutrofilów (antineutrophil cytoplasmic antibodies - ANCA) przy braku lub jedynie skąpej ilości kompleksów immunologicznych w ścianie naczyń [1].

Zgodnie z nazewnictwem przyjętym w ramach Międzynarodowej Konferencji Chapel Hill w 2012 r. (Chapel Hill Consensus Conference - CHCC) spośród rodzajów AAV wyróżnia się:

- mikroskopowe zapalenie naczyń (microscopic polyangitis - MPA),
- ziarniniakowatość z zapaleniem naczyń (granulomatosis with polyangitis - GPA),

- eozynofilową ziarniniakowatość z zapaleniem naczyń (eosinofilic granulomatosis with polyangitis - EGPA).

Pełny podział zapaleń naczyń przyjętych w ramach CHCC z 2012 r. przedstawiono w tabeli 1 [1]. Wyróżnia się również ograniczone narządowo formy AAV, szczególnie dotyczące płuc lub nerek. Należy odróżniać te zapalenia od zapaleń naczyń jednego narządu. Choroba objawiająca się tylko w jednej lokalizacji może być początkiem choroby układowej. Postawienie rozpoznania zapalenia naczyń jednego narządu powinno więc być stawiane po czasie potrzebnym do stwierdzenia braku zmian chorobowych w innych lokalizacjach [2]. Jako punkt odcięcia sugeruje się 6-miesięczny okres, po którym nie stwierdza się cech progresji do choroby układowej [3]. 
TABELA 1. Nazewnictwo zapaleń naczyń według Międzynarodowej Konferencji Chapel Hill w 2012 r.

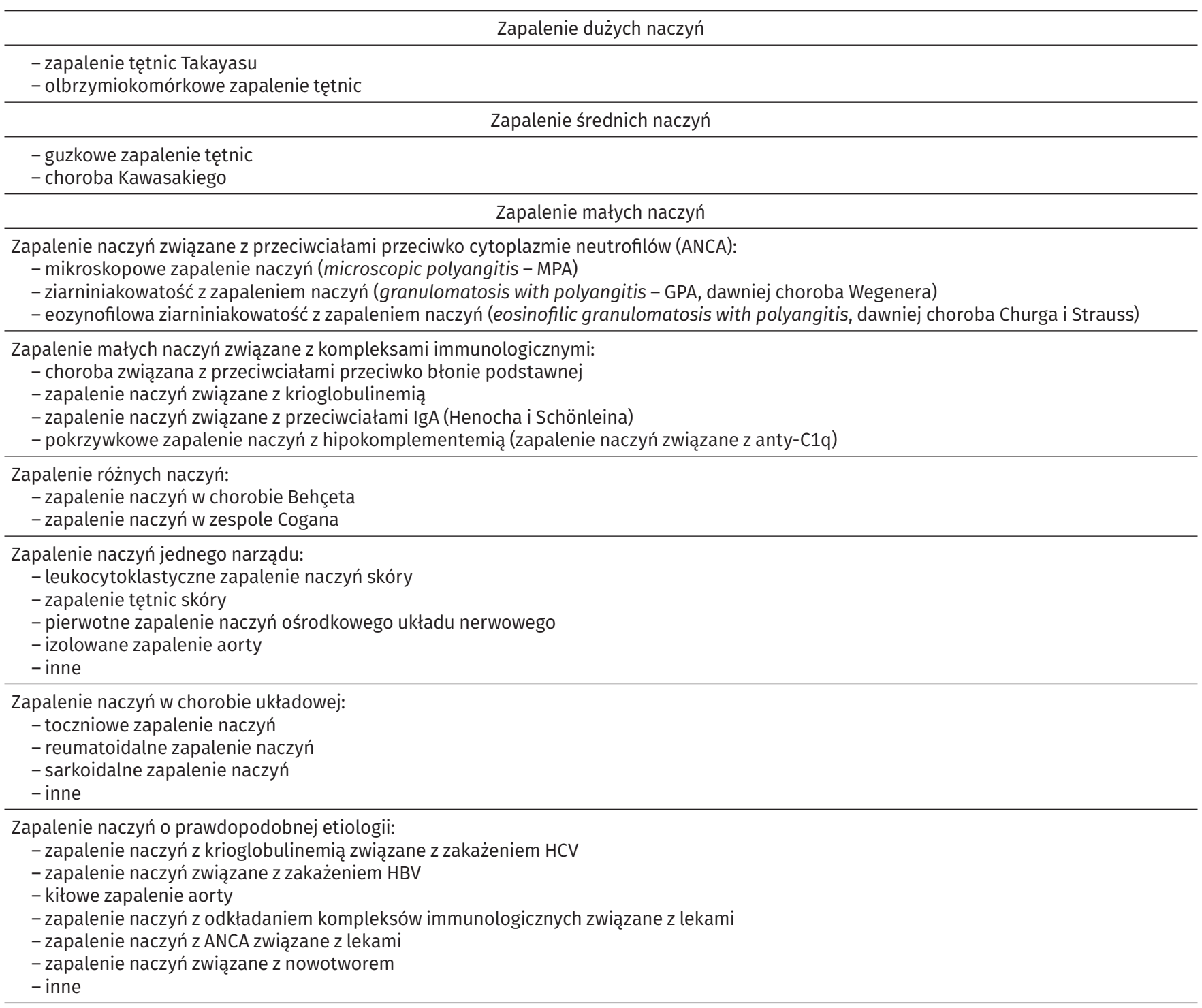

\section{Przeciwciała przeciwko cytoplazmie neutrofilów}

Przeciwciała przeciwko cytoplazmie neutrofilów to przeciwciała klasy G (IgG) skierowane przeciwko składnikom ziarnistości granulocytów obojętnochłonnych. Zostały po raz pierwszy opisane u pacjentów z ubogoimmunologicznym kłębuszkowym zapaleniem nerek [4], a w 1985 r. powiązano je z ziarniniakowatością z zapaleniem naczyń [5]. Ze względu na typ fluorescencji w badaniu metodą immunofluorescencji pośredniej wyróżnia się 2 typy świecenia:

- cytoplazmatyczny (cytoplasmic - c-ANCA) - charakteryzujący się fluorescencją całej cytoplazmy z centralnym zagęszczeniem w jądrze komórkowym,

- okołojądrowy (perinuclear - p-ANCA) - charakteryzujący się największą fluorescencją wokół jądra komórkowego.

Najlepiej poznane autoantygeny dla ANCA, mające znaczenie kliniczne w leczeniu AAV, to mieloperoksydaza (MPO) i proteinaza-3 (PR3). Obecność c-ANCA wiąże się zwykle z obecnością PR3-ANCA, natomiast p-ANCA z MPO-ANCA [6].

Obecność ANCA nie zawsze musi oznaczać toczący się proces chorobowy. Małe miana przeciwciał skierowanych przeciwko MPO i PR3 opisywano u osób zdrowych, chociaż cechowały się one niską awidnością i mniejszymi zdolnościami do aktywacji neutrofilów. Pozostaje niejasne, czy w większych mianach nie miałyby znaczenia patogenicznego [7, 8]. Warto zwrócić uwagę, że ANCA skierowane przeciwko innym antygenom niż wymienione (np. przeciwko laktoferynie, katalazie, alfa-enolazie lub białku bakteriobójczemu zwiększającemu przepuszczalność) mogą być wykryte również w innych jednostkach chorobowych, takich jak np. nieswoiste zapalenia jelit (w ok. 60\% przypadków wrzodziejącego zapalenia jelita grubego i w ok. 20\% przypadków u pacjentów z chorobą Leśniowskiego-Crohna) [9, 10, 11]. U niewielkiego odsetka pacjentów $\mathrm{z}$ toczniem rumieniowatym układowym bywają obecne MPO-ANCA [12].

\section{Dowody na patogeniczne znaczenie przeciwciat przeciwko cytoplazmie neutrofilów}

Dowody na udział ANCA w patogenezie AAV pochodzą zarówno z obserwacji klinicznych, badań in vitro, jak i badań na zwierzętach (tab. 2). Pierwszym i najpowszechniej znanym jest 
TABELA 2. Dowody na patogeniczność przeciwciał przeciwko cytoplazmie neutrofilów (ANCA)

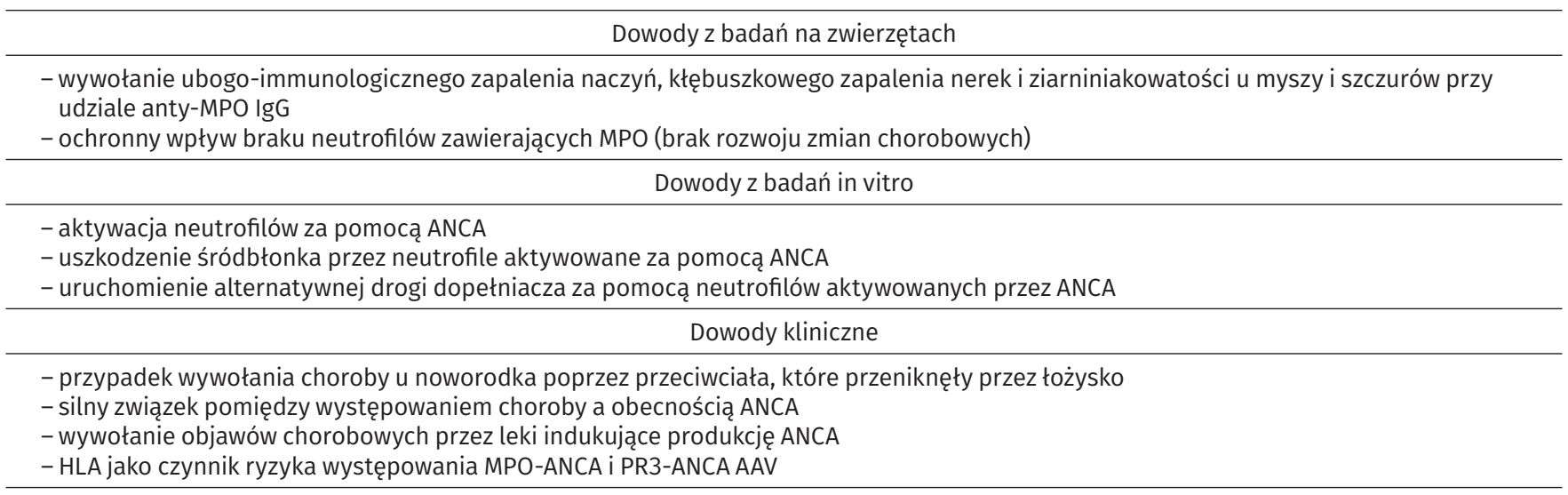

MPO - mieloperoksydaza; IgG - immunoglobuliny G; PR3 - proteinaza-3; AAV - przeciwciała przeciwko cytoplazmie neutrofilów

model na myszach zaprezentowany przez Xiao i wsp. Myszy pozbawione MPO (MPO knockout) immunizowano mysią MPO celem wytworzenia przeciwciał anty-MPO. Dożylne wstrzyknięcie tych przeciwciał myszom Rag2-/-, które pozbawione były limfocytów B i T, skutkowało wywołaniem ubogoimmunologicznego martwiczego zapalenia kłębuszków nerkowych i układowym zapaleniem małych naczyń odpowiadających ludzkiemu AAV [13].

Inny model przedstawili Schreiber i wsp. Polegał on na przeszczepieniu szpiku z komórkami zawierającymi MPO myszom uprzednio pozbawionym MPO, które immunizowano mysią MPO celem wytworzenia przeciwciał anty-MPO. Po pojawieniu się w krwiobiegu neutrofilów posiadających MPO u myszy rozwijało się kłębuszkowe zapalenie nerek. U myszy z grupy kontrolnej, którym przeszczepiono szpik pochodzący od myszy pozbawionych MPO (a więc nieposiadający neutrofilów zawierających MPO), nie rozwinęły się zmiany chorobowe [14].

Również model szczurzy - wg badania Little i wsp. potwierdza rolę ANCA w rozwoju AAV. Szczury immunizowane ludzką MPO produkowały anty-MPO, która wchodziła w reakcję krzyżową ze szczurzą MPO. W badanym modelu stwierdzono rozwój martwiczego kłębuszkowego zapalenia nerek (KZN) i zapalenia małych naczyń w płucach [15].

Dowody in vitro również przemawiają za udziałem ANCA w patogenezie AAV. Wykazano, iż podczas inkubacji MPO-ANCA lub PR3-ANCA z neutrofilami aktywowanymi czynnikami prozapalnymi (głównie czynnik martwicy nowotworu- $\alpha$, lipopolisacharydy i $\mathrm{C}_{5}$ a) dochodzi do tzw. wybuchu tlenowego (respiratory burst). W wyniku tego procesu uwalniane są wolne rodniki tlenowe, dochodzi do degranulacji i uwolnienia enzymów powodujących uszkodzenie i śmierć komórek śródbłonka [16, 17, 18, 19, 20]. W aktywowanych neutrofilach dochodzi ponadto do translokacji autoantygenów na powierzchnię komórki, co umożliwia ANCA wchodzenie z nimi w interakcje $[19,20]$.

Najprostszym klinicznym, aczkolwiek pośrednim, potwierdzeniem udziału ANCA w patogenezie AAV jest ich występowanie (MPO-ANCA lub PR3-ANCA) w ponad 90\% przypadków MPA, GPA, EGPA i martwiczego KZN [21]. Wśród dowodów klinicznych na uwagę zasługuje opis przypadku przejścia przeciwciał anty-MPO przez łożysko matki do krwiobiegu noworodka, co spowodowało krwawienie do pęcherzyków płucnych, a także rozwój zapalenia naczyń w nerkach w ciągu kilku dni po porodzie [22]. Opisano także przypadek innego noworodka, u którego nie doszło do rozwoju zmian chorobowych, pomimo stwierdzenia przejścia przeciwciał anty-MPO w wysokim mianie przez łożysko [23]. Wspierać to może teorię, że tylko część ANCA jest w rzeczywistości patogenna. Możliwe, że chorobę wywołują ANCA, które skierowane są przeciwko konkretnym epitopom danego autoantygenu.

Roth i wsp. wykazali, że autoprzeciwciała MPO-ANCA osób chorych skierowane są przeciwko innym epitopom niż MPO-ANCA wykrywane u osób zdrowych. W pracy tej wykazano także obecność przeciwciał anty-MPO skierowanych przeciwko konkretnym epitopom (konkretnej sekwencji) u osób uznawanych za chorujące na ANCA-ujemne zapalenie naczyń (wykorzystano w tym celu spektrometrię masową). Wykryte przeciwciała o powinowactwie do konkretnego regionu autoantygenu miały zdolność do aktywacji neutrofilów in vitro oraz powodowały kłębuszkowe (aczkolwiek proliferujące, a nie martwicze) zapalenie nerek u myszy [24].

Argumentem przemawiającym za udziałem ANCA w patogenezie AAV może być też remisja obserwowana u pacjentów z zapaleniem naczyń wywołanym lekami (np. propylotiouracylem, minocykliną, hydralazyną), która następowała po ich odstawieniu i włączeniu leczenia immunosupresyjnego, czemu towarzyszył również spadek miana ANCA [25]. Potwierdzeniem tezy patogennego udziału ANCA w zapaleniach naczyń jest zastosowanie kliniczne leków hamujących produkcję przeciwciał, np. na skutek deplecji limfocytów B. Leczenie to jest skuteczne w indukcji i podtrzymaniu remisji [26]. Za pomocą badań genetycznych wykazano ponadto związek niektórych antygenów, takich jak: HLA-DP, SERPINA1, PRTN3 i serpiny 6A, z występowaniem GPA i PR3-ANCA oraz związek polimorfizmu HLA-DQ z MPA i obecnością MPO-ANCA [27].

\section{Powstawanie przeciwciat przeciwko cytoplazmie neutrofilów}

Jedną z prób wyjaśnienia pochodzenia ANCA jest teoria komplementarności autoantygenów. Zakażenie niektórymi mikroorganizmami wiąże się z powstawaniem ANCA, a za przykład 
wskazać można Staphylococcus aureus i wirusa rzeki Ross (Ross river virus) [4, 28, 29]. Teoria komplementarności autoantygenów zakłada, że odpowiedź immunologiczna skierowana jest nie tyle przeciwko samemu autantygenowi, ile przeciwko peptydowi (np. bakteryjnemu), który jest komplementarny w stosunku do autoantygenu (odpowiada strukturą peptydowi antysensownemu). Peptydy komplementarne posiadają struktury i właściwości fizykochemiczne, które pozwalają im łączyć się ze sobą (tj. peptyd antysensowny z peptydem sensownym, w tym przypadku z autoantygenem). Odpowiedź immunologiczna na jeden z komplementarnych antygenów powoduje tworzenie przeciwciał skierowanych także przeciwko drugiemu (w tym przypadku przeciwko autoantygenowi) [30]. Wykazano, że przeciwciała MP3-ANCA obecne u pacjentów z AAV są reaktywne nie tylko wobec antygenów $\mathrm{PR}_{3}$, ale także wobec komplementarnych peptydów antysensownych. Sygnałem do tworzenia przeciwciał może być zarówno endogenny peptyd antysensowny, jak i peptyd egzogenny [31].

Mimikra samych autoantygenów jest również brana pod uwagę jako przyczyna tworzenia ANCA. Kain i wsp. wykazali homologię pomiędzy ludzkim epitopem lizosomalnego białka błonowego (LAMP-2) a adhezyną bakteryjną FimH, występującą wśród bakterii Gram ujemnych (np. Escherichia coli, Klebsiella pneuomoniae, Proteus mirabilis). Szczury immunizowane FimH wytwarzały przeciwciała reagujące krzyżowo z ludzkim LAMP-2. U szczurów tych rozwijało się ogniskowe martwicze KZN, a w dwóch przypadkach także zapalenie naczyń płuc, przebiegające klinicznie jako krwawienie środpęcherzykowe. Możliwe, że przeciwciała anty-LAMP-2 oddziaływają poprzez wpływ na LAMP-2, zwiększając skłonność neutrofilów do prezentowania antygenów MPO i PR3 [32]. Roth i wsp. wykazali z kolei brak zależności pomiędzy obecnością anty-LAMP-2 a aktywnością choroby. Ponadto u szczurów, którym wstrzyknięto anty-LAMP-2, nie zaobserwowano znamion choroby (nie wystąpiło kłębuszkowe zapalenie nerek) [33].

Pozostając jeszcze przy udziale patogenów w tworzeniu ANCA, warto wspomnieć, że pojawiają się doniesienia o tym, że $S$. aureus może wpływać na rozwój zmian chorobowych również poprzez aktywację neutrofilów. Miałoby do niej dochodzić poprzez receptor toll podobny 9 (TLR-9) monocytów i makrofagów. Ligandy obecne w bakteriach Gram dodatnich poprzez jego pobudzenie powodują in vitro produkcję ANCA przez limfocyty B, aktywują neutrofile, powodując uwalnianie MPO, a także są przyczyną zwiększonej ekspresji PR3 przez neutrofile [34, 35].

W postawaniu ANCA zauważa się również udział niektórych substancji chemicznych, takich jak np. hydralazyna (stosowana jako lek hipotensyjny), propylotiouracyl (stosowany w leczeniu nadczynności tarczycy) lub kokaina zanieczyszczona lewamizolem (lewamizol jest zarejestrowany jako lek przeciwpasożytniczy stosowany u bydła) [25]. Dokładny mechanizm wpływu leków na rozwój AAV pozostaje niejasny i podejrzewa się, że może być złożony. W przypadku hydralazyny jedna z hipotez zakłada jej wpływ na produkcję ANCA w sposób pośredni. Hydralazyna jest inhibitorem metylacji DNA mającym właściwości hamujące ekspresję niektórych genów na poziomie DNA. Inhibicja tego domniemanego „mechanizmu zabezpieczającego” ma prowadzić do nadekspresji antygenów MPO i PR3 [25, 36]. W przypadku propylotiouracylu bierze się natomiast pod uwagę wpływ siarczanu propylotiouracylu, który mógłby powstawać pod wpływem mieloperoksydazy uwalnianej z neutrofilów (w odpowiedzi np. na nakładającą się infekcję wirusową). Siarczan propylotiouracylu miałby wpływać na limfocyty T, a te wyzwalać dopiero dalsze reakcje prowadzące do rozwoju procesu chorobowego [37]. Szlaki powstawania ANCA przedstawiono na rycinie 1.

\section{Znaczenie NETozy i obecności zewnątrzkomórkowych sieci neutrofilowych}

Zjawisko NETozy, obok m.in. apoptozy i martwicy (nekrozy), jest jedną z form śmierci komórki, która dotyczy neutrofilów. Polega ono na uwolnieniu chromatyny jądrowej do przestrzeni zewnątrzkomórkowej. W pierwszej kolejności po aktywacji neutrofilów dochodzi do lizy błony jądra komórkowego i lizy błon ziarnistości. Uwolniona chromatyna złożona z DNA, cytrulinowanych histonów i białek ziarnistości tworzy sieci zwane zewnątrzkomórkowymi sieciami neutrofilowymi (neutrophil extracellular traps - NETs). Sieci te mają zdolności wiązania patogenów w swojej strukturze i wykazują właściwości biobójcze (zarówno poprzez właściwość samych cytrulinowanych histonów, jak i zawartych w sieci białek ziarnistości). Białka zawarte w NETs to m.in. elastaza, MPO, PR3, katepsyna G, serynowa proteinaza 4, metyloproteinaza 9, LAMP-2 [38, 39]. Wyróżnia się różne „odmiany” NETozy:

- samobójczą (suicidal NETosis) - trwającą 2-4 godz. i będącą skutkiem produkcji wolnych rodników tlenowych (reactive oxygen species - ROS) w wyniku aktywności oksydazy NADPH,

- witalną (vital NETosis) - będącą stosunkowo szybkim procesem (5-60 min), niezależnym od ROS i uruchamianym w odpowiedzi na obecność patogenu,

- mitochondrialną (mitochondrial NETosis) - uruchamianą w odpowiedzi na mitochondrialną produkcję ROS [38].

NEToza może zostać uruchomiona także przez czynniki inne niż infekcyjne, co obserwuje się np. w zakrzepicy, chorobach nowotworowych, toczniu rumieniowatym układowym, miażdżycy, cukrzycy i po ekspozycji na substancje chemiczne [38]. Nakazawa i wsp. zademonstrowali in vitro występowanie nieprawidłowej struktury i degradacji NETs w odpowiedzi na propylotiouracyl. Immunizacja szczurów Wistar Kyoto NETs powstałymi w odpowiedzi na propylotiouracyl powodowała powstanie MPO-ANCA i typowego zapalenia naczyń z zajęciem nerek i płuc [40]. Pojawienie się sieci neutrofilowych jest źródłem wielu autoantygenów (w tym MPO i PR3), a ich prezentacja przez komórki prezentujące antygen może być przyczyną tworzenia ANCA [41]. Z drugiej strony również same ANCA mogą być inicjatorem aktywacji neutrofilów, co prowadzi do NETozy. Niewykluczone, że oba scenariusze przeplatają się, napędzając „błędne koło” produkcji ANCA i aktywacji coraz to większej ilości neutrofilów [42]. 


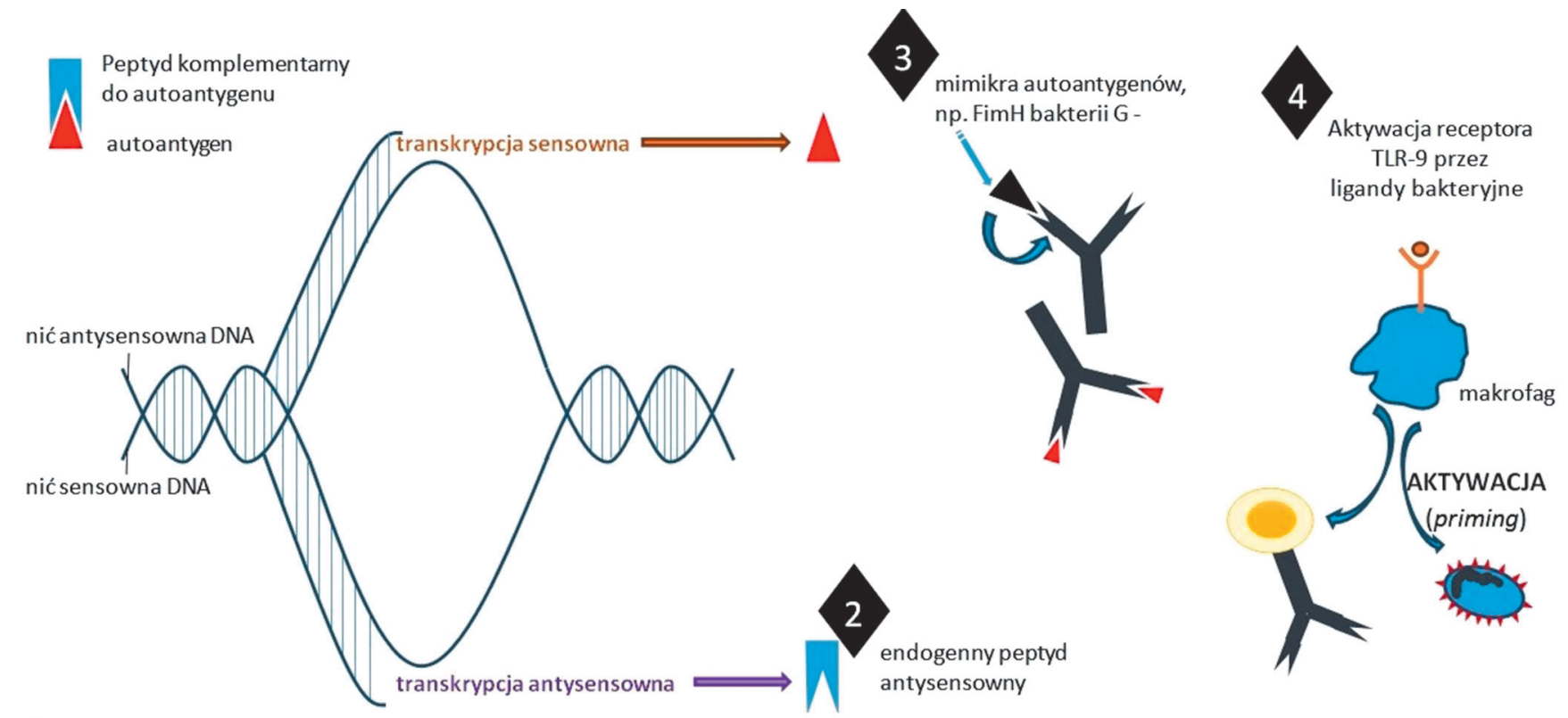

1

Mikroorganizmyjako źródło mimikry peptydu antysensownego, np. antygeny S. aureus lub RRV
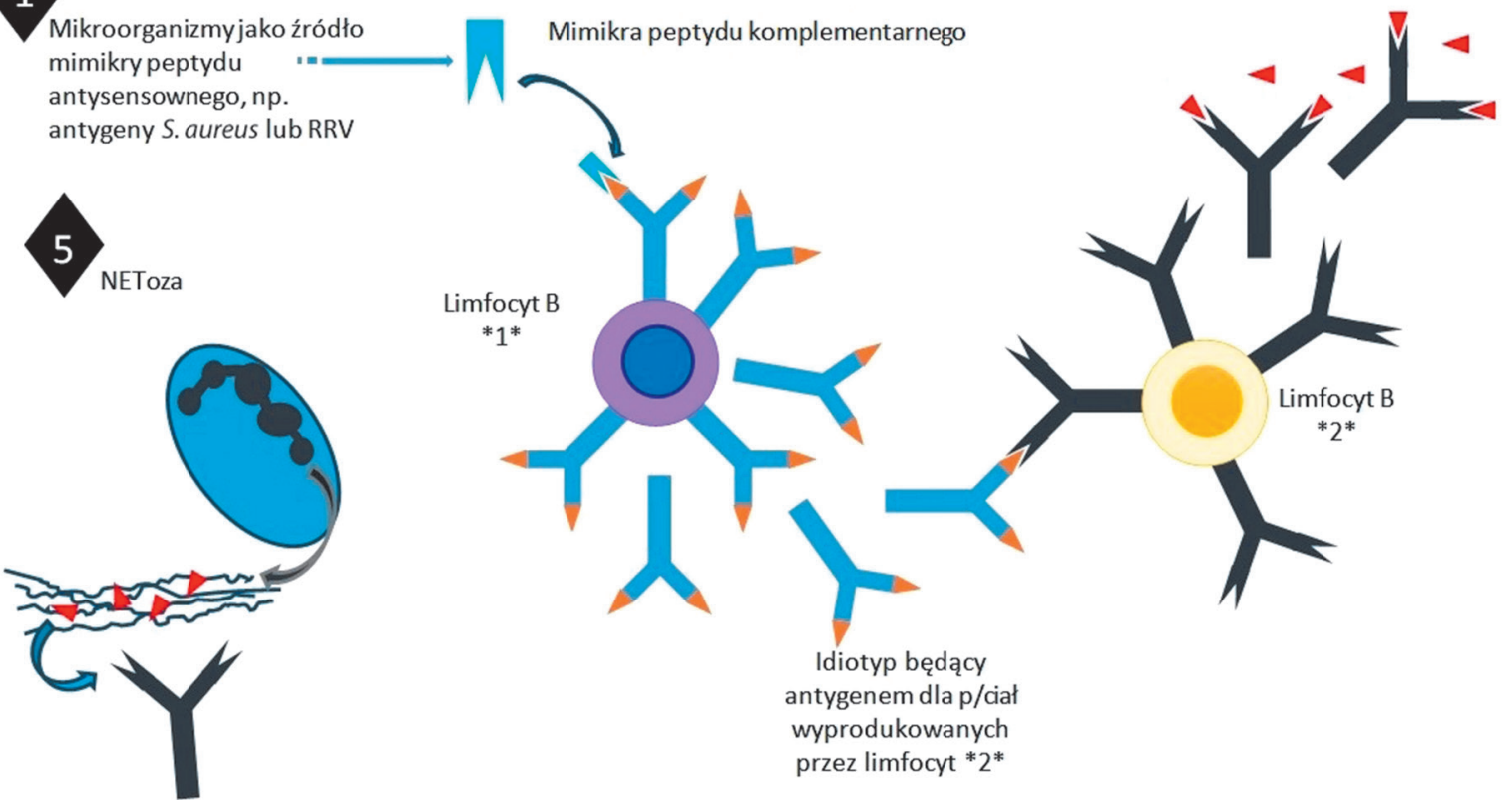

RYCINA 1. Wybrane ścieżki prowadzące do tworzenia przeciwciał przeciwko cytoplazmie neutrofilów (ANCA). Różne teorie tworzenia ANCA: teoria komplementarności antygenów zakłada tworzenie ANCA w odpowiedzi na idiotyp przeciwciała powstałego na skutek pojawienia się w organizmie mimikry peptydu komplementarnego do autoantygenu (1) lub w odpowiedzi na endogenny peptyd antysensowny (2); teoria mimikry autoantygenów zakłada podobieństwo autoantygenu z antygenem egzogennym (3); aktywacja receptora TLR-9 monocytów i makrofagów przez ligandy bakteryjne powoduje aktywację (priming) neutrofilów oraz pobudzenie limfocytów B do produkcji ANCA (4); udział NETozy postrzegany może być jako źródło autoantygenów ulegających ekspozycji po wytworzeniu NETs (5)

\section{Udział dopełniacza w patogenezie zapalenia naczyń związanego z przeciwciałami przeciwko cytoplazmie neutrofilów}

Ostatnio podkreśla się rolę dopełniacza w patomechanizmie AAV, mimo iż początkowo nie wiązano go z tą grupą jednostek chorobowych z uwagi na brak lub znikomą ilość kompleksów immunologicznych wykrywanych w ścianie naczyń [43]. Pierwsze doniesienia świadczące o roli dopełniacza pochodzą z modelu na zwierzętach Xiao i wsp., w którym badano rozwój rozplemowego zewnątrzwłośniczkowego KZN przebiegającego z martwicą naczyń (synonim: gwałtownie postępujące kłębuszkowe zapalenie nerek - GPKZN; histologicznie: rozplemowe zewnątrzwłośniczkowe kłębuszkowe zapalenie nerek z obecnymi półksiężycami w co najmniej 50\% kłębuszków nerkowych). W pracy wykorzystano myszy pozbawione odpowiednio składowej $\mathrm{C}_{5}$ dopełniacza ( $\mathrm{C}_{5}-/-$ ), składowej C4 (C4-/-) i czynnika B (B-/-). Po wstrzyknięciu przeciwciał IgG anty-MPO myszom $\mathrm{C}_{4}$-/- doszło do rozwoju zmian chorobowych w porównywalnym stopniu jak u myszy z grupy kontrolnej („dzikich”, bez deficytów). Jednak u myszy 
B-/- i C5-/- nie rozwinęło się KZN. W celu potwierdzenia roli drogi alternatywnej (z uwagi na czynnik B), jak i znaczenia składowej $\mathrm{C}_{5}$ dopełniacza w patogenezie AAV wyizolowano przeciwciała IgG pacjentów z aktywnym procesem chorobowym (zarówno MPO-ANCA, jak i PR3-ANCA) oraz od zdrowych osób (grupa kontrolna). Inkubacja MPO-ANCA lub PR3-ANCA z ludzkimi neutrofilami powodowała uwolnienie czynników aktywujących dopełniacz, co nie zachodziło po inkubacji IgG grupy kontrolnej z neutrofilami. Wobec powyższego autorzy pracy zasugerowali, że ANCA stymulując neutrofile, powodują uwolnienie czynników aktywujących alternatywną drogę dopełniacza, którego pobudzenie powoduje z kolei aktywację (priming) kolejnych neutrofilów (szczególnie poprzez C5a), tworząc błędne, samonapędzające się koło i przyspieszając rozwój zmian chorobowych [44].

Opisane doniesienie przyczyniło się do badania nowych punktów uchwytu potencjalnych terapii AAV - ukierunkowując się na inhibicji składowej $\mathrm{C}_{5}$, $\mathrm{C}_{5}$ a oraz receptora dla $\mathrm{C}_{5}$ a - $\mathrm{C}_{5} \mathrm{aR}$. Huugen i wsp. wykazali, że zahamowanie układu dopełniacza na poziomie składowej $\mathrm{C}_{5}$ zapobiega rozwojowi KZN zależnego od MPO-ANCA. W pracy wykorzystano monoklonalne przeciwciało BB5.1 skierowane przeciwko składowej C5 dopełniacza. Jednej grupie myszy podano je 8 godz. przed indukcją choroby, a drugiej grupie 24 godz. po podaniu czynników indukujących MPO-ANCA i lipopolisacharydów. U myszy, którym podano wcześniej BB5.1, nie rozwinęły się zmiany chorobowe. Blokada $\mathrm{C}_{5}$ dobę po indukcji choroby powodowała z kolei istotną poprawę, rozumianą jako wycofywanie się nieprawidłowości w badaniu moczu oraz $80 \%$ redukcja zmian histopatologicznych w kłębuszkach [45]. Eculizumab (humanizowane przeciwciało monoklonalne przeciwko składowej $\mathrm{C}_{5}$ dopełniacza), poprawiające rokowanie u pacjentów z napadową nocną hemoglobinurią i atypowym zespołem hemolityczno-mocznicowym $[46,47,48]$, może okazać się pomocne w leczeniu AAV.

W 2009 r. Schreiber i wsp. w modelu na myszach wykazali, że zablokowanie receptora dla $\mathrm{C}_{5}$ a ( $\left.\mathrm{C}_{5} \mathrm{aR}\right)$ chroni przed rozwojem ANCA-zależnego KZN. W pracy wykorzystano osocze zawierające C3a i C5a z neutrofilami aktywowanymi ANCA. Jego zastosowanie powodowało wzmożoną ekspresję PR3 na neutrofilach oraz aktywowało neutrofile do produkcji reaktywnych form tlenu po ekspozycji tych neutrofilów na ANCA. U myszy, którym zablokowano $\mathrm{C}_{5} \mathrm{aR}$, nie rozwinęły się zmiany chorobowe [18].

Modele zwierzęce wspierające potencjalną rolę aktywacji $\mathrm{C}_{5} \mathrm{w}$ patogenezie AAV potwierdzają wyniki badań przeprowadzanych w ostatnim czasie u pacjentów. W badaniu z użyciem mikroskopu elektronowego, w którym przebadano 126 bioptatów nerek pacjentów z gwałtownie postępującym KZN związanym z ANCA, wykazano u 54\% obecność złogów immunoglobulin [49]. Gou i wsp. zaobserwowali z kolei, że u pacjentów z AAV w aktywnej fazie choroby stężenia C3a, C5a, rozpuszczalnej frakcji $\mathrm{C}_{5} \mathrm{~b}-9$ i Bb były istotnie większe niż u pacjentów w fazie remisji. Stężenie properdyny wykazywało odwrotną korelację. Ponadto stężenie Bb korelowało z aktywnością choroby rozumianą jako stopień zajęcia kłębuszków nerkowych, wartościami odczynu Biernackiego i z punktacją aktywności zapalenia naczyń wg Birmingham (Birmingham Vasculitis Activity Score) [50].

W badaniu na myszach z 2014 r. Xiao i wsp. udowodnili, że podanie antagonisty receptora dla C5a (C5aR, CD 88) pod roboczą nazwą CCX168 łagodziło przebieg choroby w MPO-ANCA-zależnym GPKZN, co przejawiało się redukcją obecności półksiężyców w kłębuszkach nerkowych (30,4\% vs 3,3\%) oraz redukcją krwiomoczu, białkomoczu i leukocyturii [51]. Przeprowadzona została II faza badań klinicznych nad CCX168 (nazwa handlowa Avacopan) w AAV (https://clinicaltrials.gov, identyfikator badania: NCT01363388). Wstępne doniesienia wskazywały, że stosowanie CCX168 w połączeniu z cyklofosfamidem jest co najmniej równie skuteczne co cyklofosfamid w połączeniu z wysokimi dawkami sterydów u pacjentów z AAV [52]. Najnowsze doniesienia na tym etapie, zaprezentowane podczas kongresu ERA-EDTA w Wiedniu (53rd ERA-EDTA Congress, 2016), potwierdzają bezpieczeństwo i skuteczność CCX168 stosowanego w połączeniu z rytuksymabem lub cyklofosfamidem zamiast standardowo stosowanych wysokich dawek sterydów [53].

\section{Udział limfocytów B i T w patogenezie zapalenia naczyń związanego z przeciwciałami przeciwko cytoplazmie neutrofilów}

Regulatorowe limfocyty T (Treg) i regulatorowe limfocyty B (Breg) w mechanizmie down-regulation powinny tłumić możliwość tworzenia ANCA przez limfocyty B. Tymczasem u pacjentów z AAV nie dochodzi do takiej supresji, na co wydaje się wpływać upośledzona funkcja supresyjna Treg i Breg oraz nadmierna aktywacja limfocytów B spowodowana aktywowanymi neutrofilami [54].

Pacjenci z AAV wykazują ilościowy i jakościowy deficyt limfocytów Treg [55, 56]. Populacje limfocytów T pomocniczych CD4+ rozróżniane są na podstawie antygenów powierzchniowych i poprzez produkowane przez nie cytokiny, np. limfocyty Th1 charakteryzują się produkcją interferonu gamma, limfocyty Th2 produkcją interleukiny 4, limfocyty Th17 produkcją interleukiny 17, a limfocyty Treg wysoką ekspresją CD25 i FoxP3. Morgan i wsp. zaobserwowali, że pacjenci z aktywną postacią AAV mają zwiększoną ilość limfocytów CD4+ CD25+, ale zmniejszoną ekspresję FoxP3+. Ponadto pacjenci ze zwiększoną pulą limfocytów $\mathrm{CD}_{4}+\mathrm{FoxP}_{3}+$ szybciej osiągali remisję choroby [55]. Free i wsp. zaważyli natomiast zwiększoną ilość Treg FoxP 3 + wśród pacjentów z aktywnym AAV, ale limfocyty te wykazywały mniejsze właściwości supresorowe z powodu obecności izoformy FoxP3 z brakującym eksonem drugim, co jak się okazało - wpływa na upośledzenie funkcji hamującej odpowiedź immunologiczną [56].

Podobnie jak wśród limfocytów T, tak i wśród limfocytów B zaobserwować można zróżnicowanie fenotypowe i zmiany aktywności u chorych na AAV. Wśród pacjentów z GPA zauważono zwiększony odsetek limfocytów B CD38+ [57] i wykazano, że większa ekspresja CD19+ u pacjentów z AAV wiąże się z większą produkcją przeciwciał [58]. Ciekawą korelację wykazano dla limfocytów regulatorowych B CD5+. Brunch i wsp. zaobserwowali, że pacjenci z aktywnym AAV mają 
niższe stężenia krążących limfocytów B CD5+, podczas gdy ich stężenie u pacjentów w remisji odpowiadało stężeniom typowym dla osób zdrowych. Co więcej, normalizacja stężenia $\mathrm{CD}^{+}$u pacjentów po leczeniu rytuksymabem korelowała $\mathrm{z}$ trwalszą remisją [59].

Nie tylko defekt supresji Treg i Breg, lecz również nadmierna stymulacja limfocytów B przez neutrofile aktywowane przez ANCA ma wpływ na aktywność choroby. Neutrofile uwalniają wiele mediatorów, w tym czynnik aktywujący i stymulujący limfocyty B BAFF/BlyS (B-cell-activating factor/B lymphocyte stimulator). Badania wykazują zwiększone stężenia tego czynnika u pacjentów z AAV, co może korelować z aktywnością choroby, chociaż istnieją sprzeczne doniesienia na temat korelacji jego stężenia z mianem ANCA [60, 61, 62, 63]. Na rycinie 2 podsumowano ścieżki patogenetyczne w AAV.

\section{WNIOSKI}

Tworzenie ANCA i powstawanie zmian chorobowych u pacjentów z AAV jest procesem złożonym i wieloczynnikowym. Na kluczową pozycję w tej sieci złożonych szlaków immunologicznych wysuwają się neutrofile ze względu na ich podwójną rolę - są zarówno celem dla ANCA, jak i uczestniczą w ich tworzeniu w ramach ekspozycji antygenów podczas NETozy. Neutrofile są też źródłem czynników aktywujących alternatywną

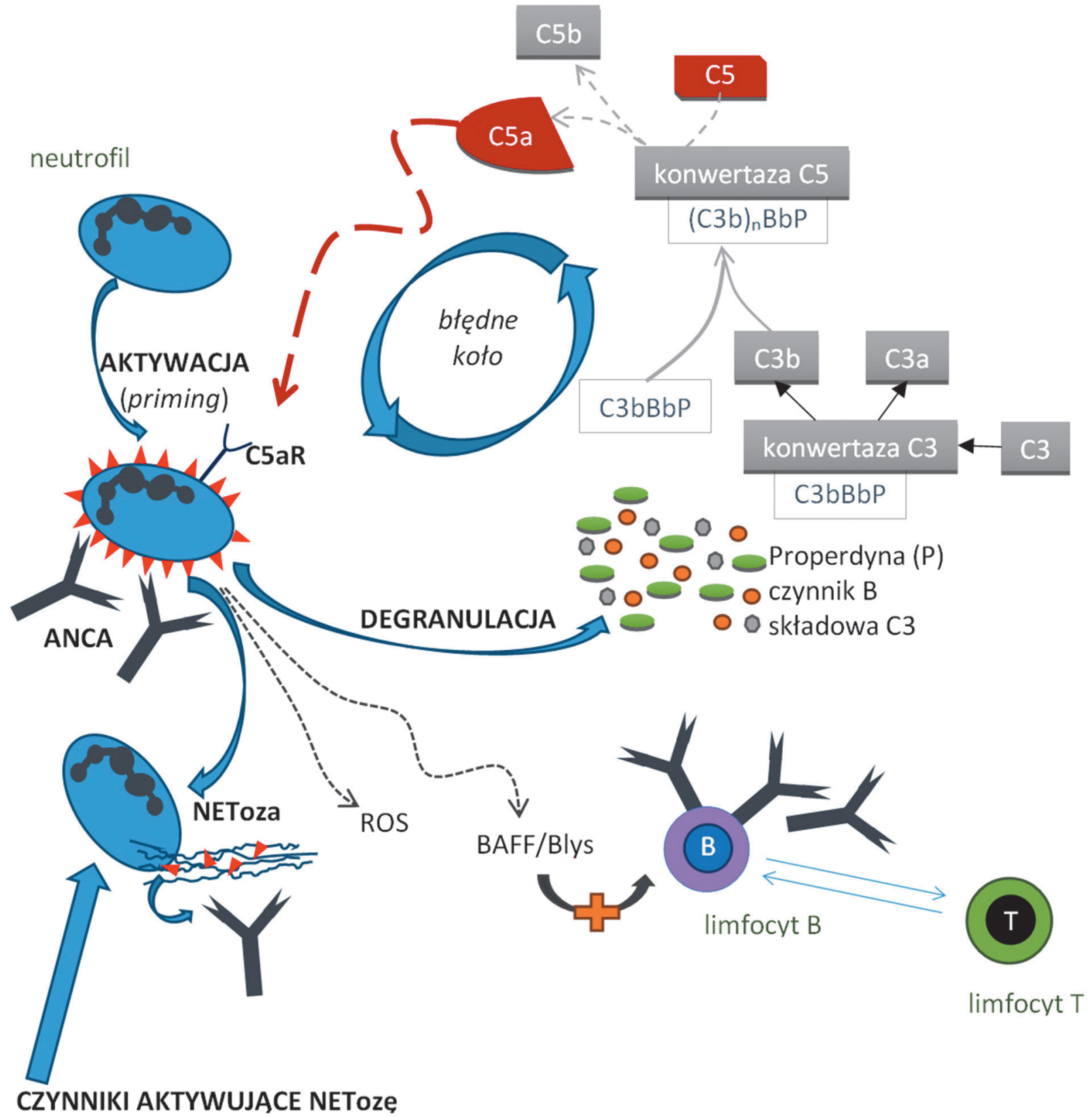

ANCA - przeciwciała przeciwko cytoplazmie neutrofilów; ROS - wolne rodniki tlenowe; BAFF/Blys - czynnik aktywujący i stymulujący limfocyty B

RYCINA 2. Ścieżki patogenetyczne zapalenia naczyń związanego z przeciwciałami przeciwko cytoplazmie neutrofilów - udział dopełniacza (z mechanizmem błędnego koła), NETozy i zależności limfocytów B i T 
drogę dopełniacza, prowadząc do powstania błędnego koła (napędzającej się pętli zdarzeń) zaostrzającego rozwój martwiczych zmian zapalnych. Kwestie deregulacji immunologicznej z udziałem limfocytów B i T wymagają dalszych badań nie tylko ze względu na potencjalny punkt uchwytu leczenia, ale również z powodu doniesień dotyczących populacji CD5+ jako markera aktywności choroby i jej przebiegu. Chociaż na polu patogenezy ANCA-zależnych zapaleń naczyń wiele ścieżek pozostaje otwartych, to jednak nowe doniesienia pozwalają lepiej zrozumieć szlaki powstawania zmian chorobowych. Stwarza to szanse na skuteczniejsze lub co najmniej równie skuteczne metody leczenia jak obecnie stosowane, przy ograniczeniu działań niepożądanych, a także daje nadzieję na wyodrębnienie markerów aktywności choroby.

\section{PIŚMIENNICTWO}

1. Jennette JC, Falk RJ, Bacon PA, Basu N, Cid MC, Ferrario F, et al. 2012 revised International Chapel Hill Consensus Conference Nomenclature of Vasculitides. Arthritis Rheum 2013;65(1):1-11. doi: 10.1002/art.37715.

2. Atisha-Fregoso Y, Hinojosa-Azaola A, Alcocer-Varela J. Localized, single organ vasculitis: clinical presentation and management. Clin Rheumatol 2013;32(1):1-6. doi: 10.1007/s10067-012-2069-2.

3. Hernandez-Rodriguez J, Hoffman GS. Updating single-organ vasculitis. Curr Opin Rheumatol 2012;24(1):38-45. doi: 10.1097/BOR.0b013e32834d8482.

4. Davies DJ, Moran JE, Niall JF, Ryan GB. Segmental necrotising glomerulonephritis with antineutrophil antibody: possible arbovirus aetiology? Br Med J (Clin Res Ed) 1982;285(6342):606.

5. van der Woude FJ, Rasmussen N, Lobatto S, Wiik A, Permin H, van Es LA, et al. Autoantibodies against neutrophils and monocytes: tool for diagnosis and marker of disease activity in Wegener's granulomatosis. Lancet 1985;1(8426):425-9.

6. Noone D, Hebert D, Licht C. Pathogenesis and treatment of ANCA-associated vasculitis - a role for complement. Pediatr Nephrol 2018;33(1):111. doi: 10.1007/s00467-016-3475-5.

7. Cui Z, Zhao MH, Segelmark M, Hellmark T. Natural autoantibodies to myeloperoxidase, proteinase 3 , and the glomerular basement membrane are present in normal individuals. Kidney Int 2010;78(6):590-7. doi: 10.1038/ ki.2010.198.

8. Xu PC, Cui Z, Chen M, Hellmark T, Zhao MH. Comparison of characteristics of natural autoantibodies against myeloperoxidase and anti-myeloperoxidase autoantibodies from patients with microscopic polyangiitis. Rheumatology (Oxford) 2011;50(7):1236-43. doi: 10.1093/rheumatology/ker085.

9. Roozendaal C, Pogány K, Horst G, Jagt TG, Kleibeuker JH, Nelis GF, et al. Does analysis of the antigenic specificities of anti-neutrophil cytoplasmic antibodies contribute to their clinical significance in the inflammatory bowel diseases? Scand J Gastroenterol 1999;34(11):1123-31.

10. Ooi CJ, Lim BL, Cheong WK, Ling AE, Ng HS. Antineutrophil cytoplasmic antibodies (ANCAs) in patients with inflammatory bowel disease show no correlation with proteinase 3, lactoferrin, myeloperoxidase, elastase, cathepsin G and lysozyme: a Singapore study. Ann Acad Med Singapore 2000;29(6):704-7.

11. Mahler M, Bogdanos DP, Pavlidis P, Fritzler MJ, Csernok E, Damoiseaux J, et al. PR3-ANCA: a promising biomarker for ulcerative colitis with extensive disease. Clin Chim Acta 2013;424:267-73. doi: 10.1016/j.cca.2013.06.005.

12. Hervier B, Hamidou M, Haroche J, Durant C, Mathian A, Amoura Z. Systemic lupus erythematosus associated with ANCA-associated vasculitis: an overlapping syndrome? Rheumatol Int 2012;32(10):3285-90. doi: 10.1007/s00296-011-2055-Z

13. Xiao H, Heeringa P, Hu P, Liu Z, Zhao M, Aratani Y, et al. Antineutrophil cytoplasmic autoantibodies specific for myeloperoxidase cause glomerulonephritis and vasculitis in mice. J Clin Invest 2002;110(7):955-63. doi: 10.1172/JCI15918.

14. Schreiber A, Xiao H, Falk RJ, Jennette JC. Bone marrow-derived cells are sufficient and necessary targets to mediate glomerulonephritis and vasculitis induced by anti-myeloperoxidase antibodies. J Am Soc Nephrol 2006;17(12):3355-64. doi: 10.1681/ASN.2006070718.

15. Little MA, Smyth L, Salama AD, Mukherjee S, Smith J, Haskard D, et al. Experimental autoimmune vasculitis: an animal model of anti-neutrophil cytoplasmic autoantibody-associated systemic vasculitis. Am J Pathol 2009;174(4):1212-20. doi: 10.2353/ajpath.2009.080458.

16. Falk RJ, Terrell RS, Charles LA, Jennette JC. Anti-neutrophil cytoplasmic autoantibodies induce neutrophils to degranulate and produce oxygen radicals in vitro. Proc Natl Acad Sci U S A 1990;87(11):4115-9.

17. Lu X, Garfield A, Rainger GE, Savage CO, Nash GB. Mediation of endothelial cell damage by serine proteases, but not superoxide released from antineutrophil cytoplasmic antibody-stimulated neutrophils. Arthritis Rheum 2006;54(4):1619-28. doi: 10.1002/art.21773.

18. Schreiber A, Xiao H, Jennette JC, Schneider W, Luft FC, Kettritz R. C5a receptor mediates neutrophil activation and ANCA-induced glomerulonephritis. J Am Soc Nephrol 2009;20(2):289-98. doi: 10.1681/ASN.2008050497.

19. Kettritz R, Jennette JC, Falk RJ. Cross-linking of ANCA-antigens stimulates superoxide release by human neutrophils. J Am Soc Nephrol 1997;8(2):38694.

20. Williams JM, Ben-Smith A, Hewins P, Dove SK, Hughes P, McEwan R, et al. Activation of the $G$ heterotrimeric $G$ protein by ANCA IgG F $\left(a^{\prime}\right) 2$ fragments is necessary but not sufficient to stimulate the recruitment of those downstream mediators used by intact ANCA IgG. J Am Soc Nephrol 2003;14(3):661-9.

21. Eisenberger U, Fakhouri F, Vanhille P, Beaufils H, Mahr A, Guillevin L, et al. ANCA-negative pauci-immune renal vasculitis: histology and outcome. Nephrol Dial Transplant 2005;20(7):1392-9. doi: 10.1093/ndt/gfh830.

22. Bansal PJ, Tobin MC. Neonatal microscopic polyangiitis secondary to transfer of maternal myeloperoxidase-antineutrophil cytoplasmic antibody resulting in neonatal pulmonary hemorrhage and renal involvement. Ann Allergy Asthma Immunol 2004;93(4):398-401. doi: 10.1016/S10811206(10)61400-7.

23. Silva F, Specks U, Sethi S, Irazabal MV, Fervenza FC. Successful pregnancy and delivery of a healthy newborn despite transplacental transfer of antimyeloperoxidase antibodies from a mother with microscopic polyangiitis. Am J Kidney Dis 2009;54(3):542-5. doi: 10.1053/j.ajkd.2009.02.016.

24. Roth AJ, Ooi JD, Hess JJ, van Timmeren MM, Berg EA, Poulton CE, et al. Epitope specificity determines pathogenicity and detectability in ANCAassociated vasculitis. J Clin Inves 2013;123(4):1773-83. doi: 10.1172/ JCI65292.

25. Pendergraft WF 3rd, Niles JL. Trojan horses: drug culprits associated with antineutrophil cytoplasmic autoantibody (ANCA) vasculitis. Curr Opin Rheumatol 2014;26(1):42-9. doi: 10.1097/BOR.0000000000000014.

26. Jones RB. Rituximab in the treatment of anti-neutrophil cytoplasm antibody-associated vasculitis. Nephron Clin Pract 2014;128(3-4):243-9. doi: $10.1159 / 000368580$.

27. Lyons PA, Rayner TF, Trivedi S, Holle JU, Watts RA, Jayne DR, et al. Genetically distinct subsets within ANCA-associated vasculitis. N Engl J Med 2012;367(3):214-23. doi: 10.1056/NEJMoa1108735.

28. Popa ER, Stegeman CA, Kallenberg CG, Tervaert JW. Staphylococcus aureus and Wegener's granulomatosis. Arthritis Res 2002;4(2):77-9. doi: $10.1186 / \operatorname{ar} 392$.

29. Laudien M, Gadola SD, Podschun R, Hedderich J, Paulsen J, ReinholdKeller E, et al. Nasal carriage of Staphylococcus aureus and endonasal activity in Wegener's granulomatosis as compared to rheumatoid arthritis and chronic rhinosinusitis with nasal polyps. Clin Exp Rheumatol 2010;28(Suppl. 57):51-5.

30. Heal JR, Roberts GW, Raynes JG, Bhakoo A, Miller AD. Specific interactions between sense and complementary peptides: the basis for the proteomic code. Chembiochem 2002;3(2-3):136-51.

31. Pendergraft WF 3rd, Preston GA, Shah RR, Tropsha A, Carter CW Jr, Jennette JC, et al. Autoimmunity is triggered by cPR-3(105-201), a protein complementary to the autoantigen proteinase-3. Nat Med 2004;10(1):729. doi: 10.1038/nm968.

32. Kain R, Exner M, Brandes R, Ziebermayr R, Cunningham D, Alderson CA, et al. Molecular mimicry in pauci-immune focal necrotizing glomerulonephritis. Nat Med 2008;14(10):1088-96. doi: 10.1038/nm.1874.

33. Roth AJ, Brown MC, Smith RN, Badhwar AK, Parente O, Chung HC, et al. Anti-LAMP-2 antibodies are not prevalent in patients with antineutrophil cytoplasmic autoantibody glomerulonephritis. J Am Soc Nephrol 2012;23(3):545-55. doi: 10.1681/ASN.2011030273. 
34. Tadema H, Heeringa P, Kallenberg CG. Bacterial infections in Wegener's granulomatosis: mechanisms potentially involved in autoimmune pathogenesis. Curr Opin Rheumatol 2011;23(4):366-71. doi: 10.1097/ BOR.0b013e328346c332.

35. Holle JU, Windmöller M, Lange C, Gross WL, Herlyn K, Csernok E. Toll-like receptor TLR2 and TLR9 ligation triggers neutrophil activation in granulomatosis with polyangiitis. Rheumatology (Oxford) 2013;52(7):1183-9. doi: 10.1093/rheumatology/kes415.

36. De la Cruz-Hernández E, Perez-Plasencia C, Pérez-Cardenas E, Gonzalez-Fierro A, Trejo-Becerril C, Chávez-Blanco A, et al. Transcriptional changes induced by epigenetic therapy with hydralazine and magnesium valproate in cervical carcinoma. Oncol Rep 2011;25(2):399-407. doi: 10.3892/or.2010.1086

37. von Schmiedeberg S, Goebel C, Gleichmann E, Uetrecht J. Neutrophils and drug metabolism. Science 1995;268(5210):585-6.

38. Berthelot JM, Le Goff B, Neel A, Maugars Y, Hamidou M. NETosis: At the crossroads of rheumatoid arthritis, lupus, and vasculitis. Joint Bone Spine 2017;84(3):255-62. http://dx.doi.org/10.1016/j.jbspin.2016.05.013.

39. Metzler KD, Goosmann C, Lubojemska A, Zychlinsky A, Papayannopoulos V. A myeloperoxidase-containing complex regulates neutrophil elastase release and actin dynamics during NETosis. Cell Rep 2014;8(3):883-96. doi: 10.1016/j.celrep.2014.06.044.

40. Nakazawa D, Tomaru U, Suzuki A, Masuda S, Hasegawa R, Kobayashi T, et al. Abnormal conformation and impaired degradation of propylthiouracil-induced neutrophil extracellular traps: Implications of disordered neutrophil extracellular traps in a rat model of myeloperoxidase antineutrophil cytoplasmic antibody-associated vasculitis. Arthritis Rheum 2012;64(11):3779-87. doi: 10.1002/art.34619.

41. Sangaletti S, Tripodo C, Chiodoni C, Guarnotta C, Cappetti B, Casalini P, et al. Neutrophil extracellular traps mediate transfer of cytoplasmic neutrophil antigens to myeloid dendritic cells toward ANCA induction and associated autoimmunity. Blood 2012;120(15):3007-18. doi: 10.1182/ blood-2012-03-416156.

42. Kessenbrock K, Krumbholz M, Schönermarck U, Back W, Gross WL, Werb $Z$, et al. Netting neutrophils in autoimmune small-vessel vasculitis. Nat Med 2009;15(6):623-5. doi: 10.1038/nm.1959.

43. Jenette JC, Wilkman AS, Falk RJ. Anti-neutrophil cytoplasmic autoantibodyassociated glomerulonephritis and vasculitis. Am J Pathol 1989;135:921-30.

44. Xiao H, Schreiber A, Heeringa P, Falk RJ, Jennette JC. Alternative complement pathway in the pathogenesis of disease mediated by anti-neutrophil cytoplasmic autoantibodies. Am J Pathol 2007;170(1):52-64. doi: 10.2353/ ajpath.2007.060573.

45. Huugen D, van Esch A, Xiao H, Peutz-Koostra CJ, Buurman WA, Tervaert $\mathrm{JW}$, et al. Inhibition of complement factor $\mathrm{C} 5$ protects against anti-myeloperoxidase antibody-mediated glomerulonephritis in mice. Kidney Int 2007;71(7):646-54. doi: 10.1038/sj.ki.5002103.

46. Hillmen P, Hall C, Marsh JC, Elebute M, Bombara MP, Petro BE, et al. Effect of eculizumab on hemolysis and transfusion requirements in patients with paroxysmal nocturnal hemoglobinuria. N Engl J Med 2004;350(6):552-9. doi: 10.1056/NEJMoa031688.

47. Hillmen P, Neal S, Young NS, Schubert J, Brodsky RA, Socié G, et al. The complement inhibitor eculizumab in paroxysmal nocturnal hemoglobinuria. N Engl J Med 2006;355(12):1233-43. doi: 10.1056/NEJMoa061648.

48. Legendre CM, Licht C, Muus P, Greenbaum LA, Babu S, Bedrosian C, et al. Terminal complement inhibitor eculizumab in atypical hemolytic-uremic syndrome. N Engl J Med 2013;368(23):2169-81. doi: 10.1056/NEJMoa1208981.

49. Haas M, Eustace JA. Immune complex deposits in ANCA-associated crescentic glomerulonephritis: A study of 126 cases. Kidney Int 2004;65(6):214552. doi: 10.1111/j.1523-1755.2004.00632.x.

50. Gou SJ, Yuan J, Chen M, Yu F, Zhao MH. Circulating complement activation in patients with anti-neutrophil cytoplasmic antibody-associated vasculitis. Kidney Int 2013;83(1):129-37. doi: 10.1038/ki.2012.313.

51. Xiao H, Dairaghi DJ, Powers JP, Ertl LS, Baumgart T, Wang Y, et al. C5a receptor (CD88) blockade protects against MPO-ANCA GN. J Am Soc Nephrol 2014;25(2):225-31. doi: 10.1681/ASN.2013020143.

52. Jayne DR, Bruchfeld A, Schaier M, Ciechanowski K, Harper L, Jadoul M, et al. Oral C5a receptor antagonist CCX168 phase II clinical trial in ANCAassociated renal vasculitis. Ann Rheum Dis 2014;73 Suppl 2:148.

53. Jayne D, Bruchfeld A, Harper L, Schaier M, Venning M, Hamilton P, et al. Successful steroid replacement in ANCA-associated vasculitis with C5a receptor inhibitor CCX168 in phase 2 randomised trial (CLEAR). Nephrol Dial Transplant 2016;31 Suppl 1:i45-i47.

54. Jennette JC, Falk RJ. B-cell mediated pathogenesis of ANCA-mediated vasculitis. Semin Immunopathol 2014;36(3):327-38. doi: 10.1007/s00281014-0431-y.

55. Morgan MD, Day CJ, Piper KP, Khan N, Harper L, Moss PA, et al. Patients with Wegener's granulomatosis demonstrate a relative deficiency and functional impairment of T-regulatory cells. Immunology 2010;130(1):6473. doi: 10.1111/j.1365-2567.2009.03213.x.

56. Free ME, Bunch DO, McGregor JA, Jones BE, Berg EA, Hogan SL, et al. Patients with antineutrophil cytoplasmic antibody-associated vasculitis have defective Treg cell function exacerbated by the presence of a suppression-resistant effector cell population. Arthritis Rheum 2013;65(7):192233. doi: 10.1002/art.37959.

57. Popa ER, Stegeman CA, Bos NA, Kallenberg CG, Tervaert JW. Differential B- and T-cell activation in Wegener's granulomatosis. J Allergy Clin Immunol 1999;103:885-94.

58. Culton DA, Nicholas MW, Bunch DO, Zhen QL, Kepler TB, Dooley MA, et al. Similar CD19 dysregulation in two autoantibody-associated autoimmune diseases suggests a shared mechanism of B-cell tolerance loss. J Clin Immunol 2007;27(1):53-68. doi: 10.1007/s10875-006-9051-1.

59. Bunch DO, McGregor JG, Khandoobhai NB, Aybar LT, Burkart ME, Hu Y, et al. Decreased $\mathrm{CD}^{+} \mathrm{B}$ cells in active ANCA vasculitis and relapse after rituximab. Clin J Am Soc Nephrol 2013;8(3):382-91. doi: 10.2215/CJN.03950412.

60. Scapini P, Bazzoni F, Cassatella MA. Regulation of B-cell-activating factor (BAFF)/B lymphocyte stimulator (BLyS) expression in human neutrophils. Immunol Lett 2008;116(1):1-6. doi: 10.1016/j.imlet.2007.11.009.

61. Krumbholz M, Specks U, Wick M, Kalled SL, Jenne D, Meinl E. BAFF is elevated in serum of patients with Wegener's granulomatosis. J Autoimmun 2005;25(4):298-302. doi: 10.1016/j.jaut.2005.08.004.

62. Nagai M, Hirayama K, Ebihara I, Shimohata H, Kobayashi M, Koyama A. Serum levels of BAFF and APRIL in myeloperoxidase antineutrophil cytoplasmic autoantibody-associated renal vasculitis: association with disease activity. Nephron Clin Pract 2011;118(4):c339-45. doi: 10.1159/000323393.

63. Bader L, Koldingsnes W, Nossent J. B-lymphocyte activating factor levels are increased in patients with Wegener's granulomatosis and inversely correlated with ANCA titer. Clin Rheumatol 2010;29(9):1031-5. doi: 10.1007/ s10067-010-1526-z. 